\title{
Dynamics of correlation coefficients of economic and productive characteristics depending on the age of cows
}

\author{
S.Yu. Harlap ${ }^{1,}$, A.S. Gorelik ${ }^{2}$, M.A. Bitkeeva ${ }^{1}$, N.A. Demina ${ }^{1}$, and G.M. Mullagulova ${ }^{3}$ \\ ${ }^{1}$ Ural State Agricultural University, Karl Liebknecht str., 42, 620075 Yekaterinburg, Russian \\ Federation \\ ${ }^{2}$ Ural Institute of The state fire service of the EMERCOM of Russia, Mira street, 22, Yekaterinburg, \\ Russia \\ ${ }^{3}$ K.G. Razumovsky Moscow State University of technologies and management (The First Cossack \\ University), Zemlyanoy Val, 73, 109004 Moscow, Russian Federation
}

\begin{abstract}
In 2002, a new Ural type of black-and-white breed was officially registered. Animals of this type have high productivity indicators, but at the same time there is a decrease in the productive longevity of the breeding stock. The conjugacy of milk yield for lactation is established, which allows for the first lactation to carry out selection fory milk yield. The relationship of milk yield for the first lactation weakens with the age of the animals and becomes negative for the fifth lactation. The conjugacy of such characteristics as milk yield per lactation and fat mass fraction in milk varies both by lactation and relative to milk yield per lactation. The conjugacy between milk yield and protein in milk for lactation was negative with fluctuations from low to medium-negative. For 5 lactation, there is a high positive relationship between milk yield for the first lactation and protein mass fraction in milk for 5 lactation. There are fluctuations in the correlation coefficients for fat mass fraction in milk for lactations, the conjugation of the trait with each other remains positive in the period from the first to the 4 lactation, excluding the correlation coefficient of this indicator between 1 and 5 lactation.
\end{abstract}

\section{Introduction}

Provision of the population with full-fledged food products of animal origin, including milk and dairy products - is the main necessity in ensuring the health of the nation and food security of any country [1-7]. At the same time, special attention is paid to the development of dairy cattle breeding, since the main amount, more than $97 \%$ of the total production, is obtained from cattle, a valuable food product and raw material for the dairy industry - milk. Milk provides a person with full-fledged essential nutrients and is well absorbed by the body. The increase in cow productivity is inseparably linked with milk quality improvement, which has a significant impact on the quality of finished dairy products [8-

\footnotetext{
* Corresponding author: pbio@ya.ru
} 
18]. For the production of milk in the country in recent years, the country has used dairy cattle of domestic and foreign breeding, the main livestock of which is represented by black-and-white and Holstein breeds. These are related breeds whose origin comes from Dutch cattle. Moreover, in the last few decades, systematic improvement of domestic blackand-white cattle has been carried out everywhere by pouring the blood of the world's best Holstein dairy breed. As a result of such selection and breeding work, an array of dairy cattle with a high proportion of blood on the Holstein breed was created in individual regions of the country, which differ in biological and economically useful characteristics depending on the breeding zone and breed resources used for crossing [12-16]. In the Sverdlovsk region, purebred bulls of the Holstein breed with high productive qualities according to their maternal ancestors were used on the breeding stock of the black-andwhite breed of the Ural offspring. This made it possible to create an array of highly productive black-and-white dairy cattle, which in 2002 was officially registered as a new Ural type of black-and-white breed. Animals of this type have high productivity indicators, but at the same time there is a decrease in the productive longevity of the breeding stock [17-27]. The assessment of the relationship between the productive indicators of the Ural type cows, depending on their age, is relevant and has practical significance.

The purpose of the work is to study the dynamics of the relationship of productive indicators with each other, depending on the age of cows.

\section{Materials and method}

The research was carried out in the conditions of one of the stud farms for breeding of black-and-white cattle of the Ural type. The study included all livestock that completed 5 lactation on 01.10.2020. The data of zootechnical and breeding records of the Selex database were used for the analysis. Milk productivity was taken into account by conducting control milkings once a month, milk quality indicators: fat mass fraction and protein mass fraction in milk, which were checked monthly from each cow in the conditions of the dairy laboratory of the OJSC "Uralplemcenter" of the Sverdlovsk region. Correlation coefficients were calculated for the relationship of milk yield for 305 days for lactation, milk yield - quality indicators of milk, FMF - PMF in milk for lactation.

\section{Results}

It is important to use the breeding characteristics in the selection and their relationship with each other when carrying out selection and breeding work with the herd to increase its efficiency. The farm uses holstinized black-and-white cattle of the Ural type with a high genetic productivity potential. In 2018, $9299 \mathrm{~kg}$ of milk was received from 1,391 cows, FMF and PMF in milk - 3.93 and 3.24\%, respectively.

The correlation coefficients of milk yield by lactation are presented in figure 1 . 


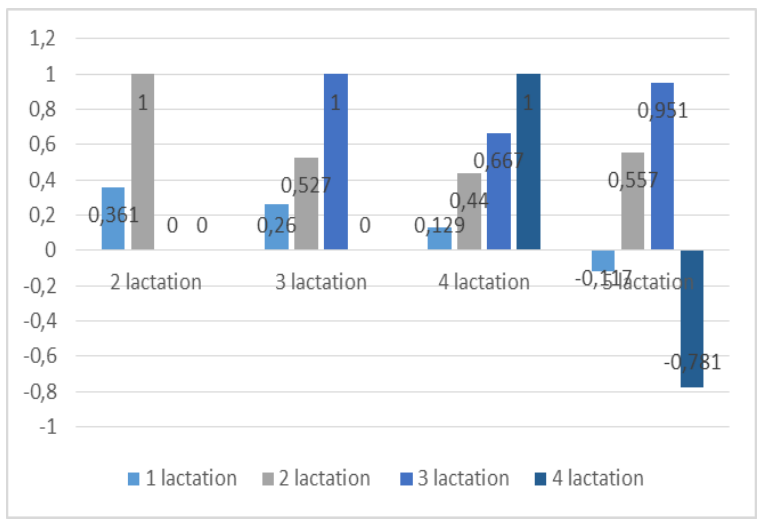

Fig. 1. Correlation coefficients of milk yield by lactation.

The calculation of the correlation coefficient of milk yield by lactation showed that in all cases, except for the correlation of milk yield for 305 days of lactation for the first-fifth lactation and the fourth-fifth lactation, positive correlation coefficients are observed, which allows to conclude that the first lactation can be selected by milk yield. The relationship of milk yield for the first lactation weakens with the age of the animals and becomes negative for the fifth lactation. The highest indicators of milk yield conjugacy for lactation are observed from the second and third to the fifth ones.

The relationship between milk yield and milk quality indicators for lactation was determined (fig. 2 and 3.).

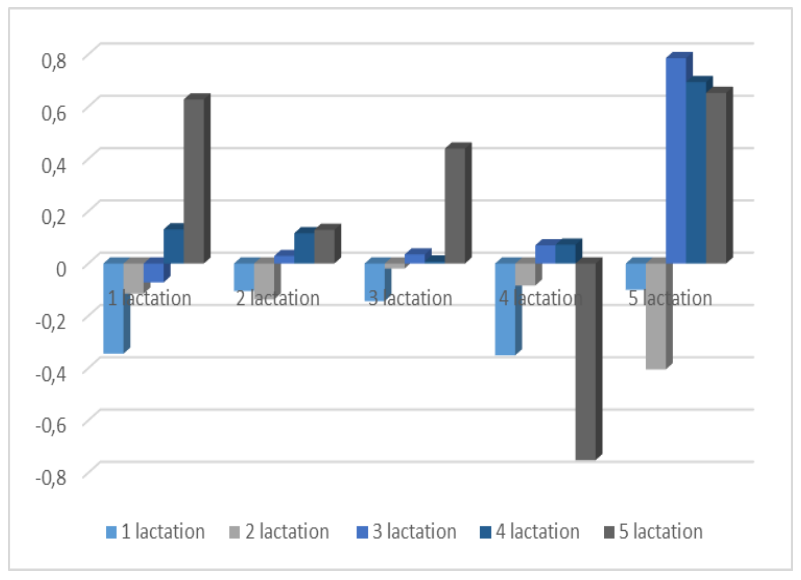

Fig. 2. Correlation coefficients between milk yield and FMF in milk by lactation.

It is clearly seen that the conjugation of such traits as milk yield per lactation and FMF in milk varies both in terms of lactation and relative to milk yield for each lactation. It was found that milk yield per lactation and FMF in milk during this lactation have a stable negative relationship, which turns into a high positive relative to the fat content in this lactation in the following ones, that is, it becomes positive with an increase in the age of cows. The exception is the conjugacy of milk yield for 4 lactation and FMF in milk for 5 lactation. Most likely, this is due to a rather sharp decrease in milk yield in 5 lactation. 


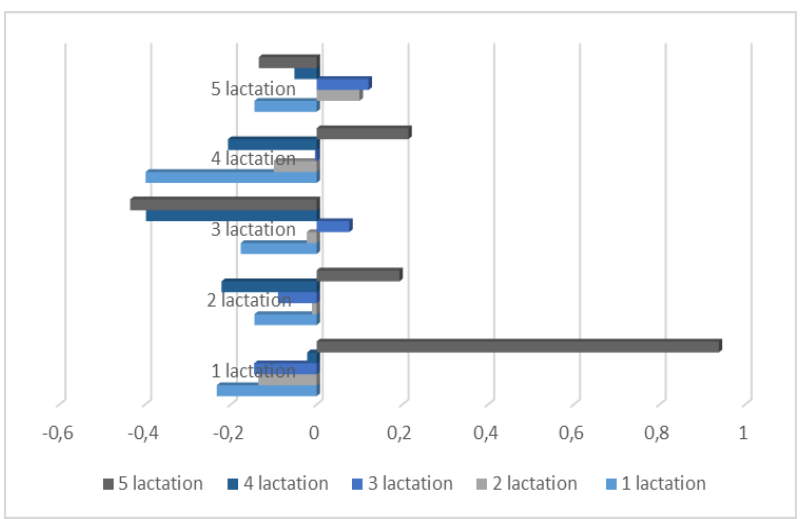

Fig. 3. Correlation coefficients between milk yield and PMF in milk by lactation.

The conjugacy between milk yield and protein in milk for lactation was negative with fluctuations from low to medium-negative (fig. 3.). For 5 lactation, there is a high positive relationship between milk yield for the first lactation and protein mass fraction in milk for 5 lactation. A low and average positive correlation between these traits has been established for the second and fourth lactation, but this, in our opinion, is an exception to the rules and cannot be taken into account when conducting breeding work.

The relationship between the qualitative indicators for lactation was also ambiguous and ranged from high negative to high positive indicators (fig. 4 and 5.).

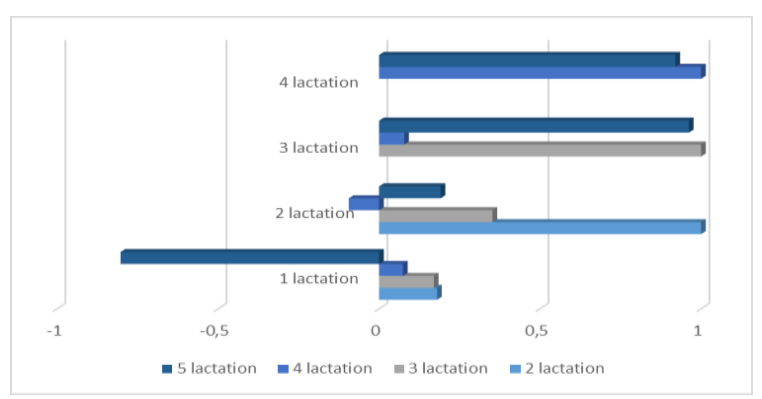

Fig. 4. The conjugation of FMF in the milk on lactation cycles.

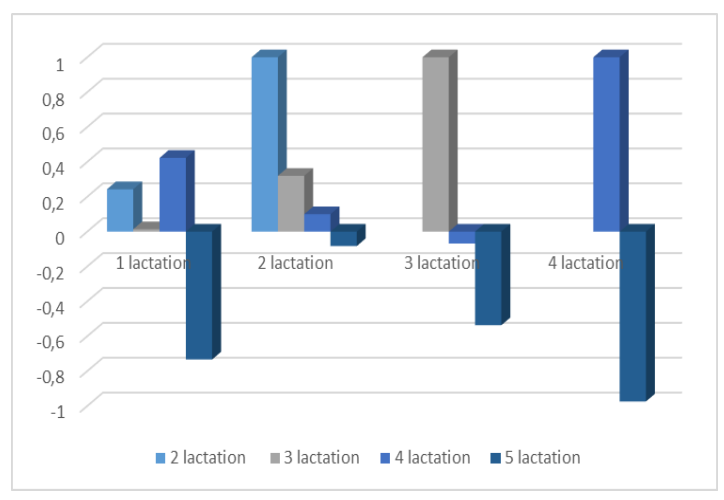

Fig. 5. Correlations of PMF in the milk on lactation cycles.

The figures show that although there are fluctuations in the correlation coefficients for fat mass fraction in milk by lactation, the conjugacy of the traits between each other in the 
period from the first to the 4 lactation remains positive, excluding the correlation coefficient of this indicator between 1 and 5 lactation. Similar data were obtained for protein mass fraction in milk, excluding the relationship with the fifth lactation (fig. 5.). A high negative conjugacy of the trait is mainly revealed here.

\section{Discussion}

The conjugation of productive traits with each other is important when conducting breeding work on the farm in order to increase the breeding value of cows. It is established that in this farm it is possible to select cows according to milk yield and milk quality indicators separately for the first lactation. Similar studies were conducted by N.V. Bogolyubova, V.P. Korotky, A.S. Zenkin, V.A. Ryzhov, N.P. Buryakov [23,24], Mymrin V and Loretts O [21], O V Gorelik, O E Lihodeevskaya, N N Zezin, M Ya Sevostyanov and O I Leshonok [25-27].

\section{Conclusion}

The relationship of milk yield for the first lactation weakens with the age of the animals and becomes negative for the fifth lactation. The highest indicators of milk yield conjugacy for lactation are observed from the second and third to the fifth ones. It was found that milk yield per lactation and FMF in milk during this lactation have a stable negative relationship, which turns into a high positive relative to the fat content in this lactation in the following ones, that is, it becomes positive with an increase in the age of cows. In this farm it is possible to select cows according to milk yield and milk quality indicators separately for the first lactation.

\section{References}

1. O. Gorelik, M. Rebezov, A. Gorelik, S. Harlap, I. Dolmatova, T. Zaitseva, N. Maksimuk, N. Fedoseeva, N. Novikova, International Journal of Innovative Technology and Exploring Engineering, 8(7), 559 (2019)

2. O. Gorelik et al, International Journal of Pharmaceutical Research (2019)

3. O. Gorelik et al, Annual Research \& Review in Biology, 18(4), 1 (2017)

4. O. Gorelik et al, AIP Conference Proceedings, 2207, 020012 (2020)

5. A. Belookov, O. Belookova, V. Zhuravel, S. Gritsenko, I. Bobyleva, E. Ermolova, S. Ermolov, Y. Matrosova, M. Rebezov, E. Ponomarev, International Journal of Engineering and Advanced Technology, 8(4), 1058 (2019)

6. F. Khaziakhmetov et al, Research Journal of Pharmaceutical, Biological and Chemical Sciences, 9(3), 866 (2018)

7. F. Khaziakhmetov, A. Khabirov, M. Rebezov, A. Basharov, I. Ziangulov, E. Okuskhanova, International Journal of Veterinary Science, 7(4), 178 (2018)

8. A. Gorelik et al, Advances in Agricultural and Biological Sciences, 2(1), 5 (2016)

9. O.V. Gorelik et al, Advances in Agricultural and Biological Sciences, 2(1), 27 (2016)

10. F. Smolnikova, Z. Moldabayeva, M. Klychkova, O. Gorelik, R. Khaybrakhmanov, I. Mironova, A. Kalimullin, G. Latypova, International Journal of Innovative Technology and Exploring Engineering, 8(7), 670 (2019)

11. N. Chernopolskaya, N. Gavrilova, M. Rebezov, S. Harlap, A. Nigmatyanov, G. 
Peshcherov, T. Bychkova, K. Vlasova, I. Karapetyan, International Journal of Pharmaceutical Research, 11(1), 545 (2019)

12. N. Chernopolskaya, N. Gavrilova, M. Rebezov, I. Dolmatova, T. Zaitseva, Y. Somova, M. Babaeva, E. Ponomarev, O. Voskanyan, International Journal of Engineering and Advanced Technology, 8(4), 40 (2019)

13. N. Gavrilova, N. Chernopolskaya, M. Rebezov, D. Moisejkina, I. Dolmatova, I. Mironova, G. Peshcherov, O. Gorelik, M. Derkho, International Journal of Recent Technology and Engineering, 8(2), 2718 (2019)

14. N. Gavrilova, N. Chernopolskaya, M. Rebezov, E. Shchetinina, I. Suyazova, S. Safronov, V. Ivanova, E. Sultanova, Journal of Critical Reviews, 7(4), 233 (2020)

15. M. Temerbayeva et al, Annual Research \& Review in Biology, 23(6), 1 (2018)

16. M. Temerbayeva et al, Research journal of pharmaceutical biological and chemical sciences, 9(1), 291 (2018)

17. A. Serikova, F. Smolnikova, M. Rebezov, E. Okuskhanova, M. Temerbayeva, O. Gorelik, S. Harlap, Sh. Baitukenova, S. Baitukenova, Y. Tumbasova, Research Journal of Pharmaceutical, Biological and Chemical Sciences, 9(4) 495 (2018)

18. F. Smolnikova, S. Toleubekova, M. Temerbayeva, E. Cherkasova, O.K. Gorelik, S. Harlap, M. Derkho, M. Rebezov, I. Penkova, Journal of Pharmaceutical, Biological and Chemical Sciences, 9(3), 1003 (2018)

19. N. Kuramshina, M. Rebezov, E. Kuramshin, L. Tretyak, G. Topuria, D. Kulikov, A. Evtushenko, S. Harlap, E. Okuskhanova, International Journal of Pharmaceutical Research, 11(1), 1301 (2019)

20. E. Skvortsov, O. Bykova, V. Mymrin, E. Skvortsova, O. Neverova, V. Nabokov, V. Kosilov, The Turkish Online Journal of Design Art and Communication, 8, 291 (2018)

21. V. Mymrin, O. Loretts, Proceedings of the International Scientific and Practical Conference (ISPC 2019) Advances in Intelligent Systems Research, 511 (2019)

22. S. Gridina, V. Gridin, O. Leshonok, Advances in Engineering Research, 253 (2018)

23. N. Bogolyubova, V. Korotky, A. Zenkin, V. Ryzhov, N. Buryakov, OnLine Journal of Biological Sciences, 17(2), 121 (2017)

24. N. Bogolyubova, V. Romanov, V. Korotky, V. Ryzhov, A. Zenkin, Asian Journal of Pharmaceutical and Clinical Research, 10(10), 117 (2017)

25. O.V. Gorelik et al, IOP Conf. Ser.: Earth Environ Sci., 548, 082009 (2020)

26. O.V. Gorelik et al, IOP Conf. Ser.: Earth Environ. Sci, (2020)

27. O. Gorelik et al, AIP Conference Proceedings, 2207, 020012 (2020) 